\title{
Is The Nation Still Imagined? Re-imagining the Filipino in the Age of Facebook in Joselito Delos Reyes' iStatus Nation
}

\section{Mark Adrian Crisostomo Ho}

\author{
De La Salle University
}

\section{Abstract}

The late historian and theorist Benedict Anderson posits that the nation is a "socially constructed community, imagined by the people who perceive themselves as part of that group"-that is, the members of a so-called "nation" simply embrace a mental image of their kinship since they neither interact with nor know each other. However, in today's age of digital globalization, where people from within and outside a community interact with each other via social media, one cannot help but ask the question: "Is the nation still imagined?" This paper attempts to answer this question by examining the relationship between nationalism and the Filipino identity in the age of Facebook as re-imagined and (re-)presented by Joselito Delos Reyes in his collection of Facebook-posts-cumpersonal-essays, iStatus Nation.

\section{Keywords}

Benedict Anderson, Joselito Delos Reyes, imagined community, iStatus Nation, Facebook 


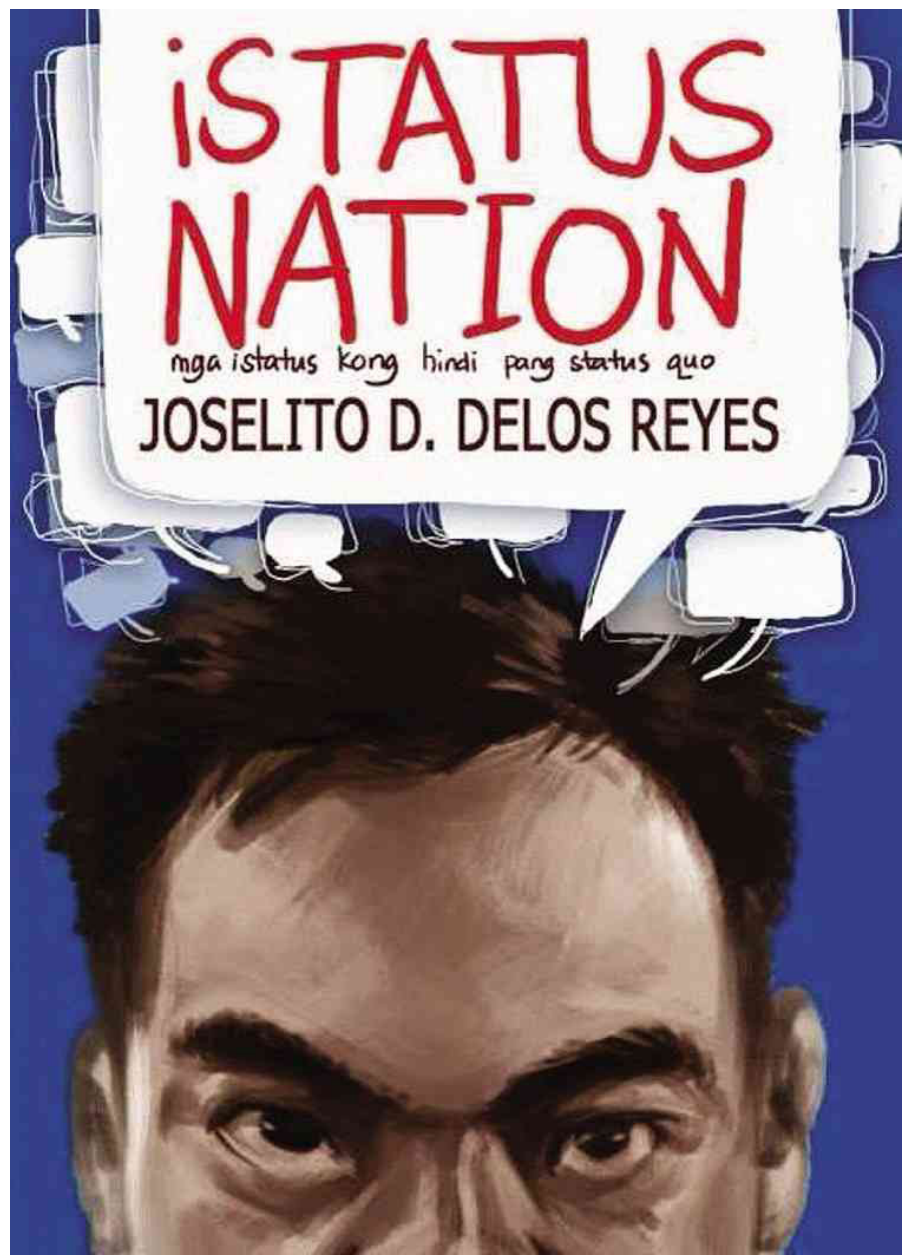

Fig. 1. Cover of iStatus Nation, Joselito Delos Reyes' collection of Facebook posts-turnedpersonal essays; https://www.goodreads.com/ 


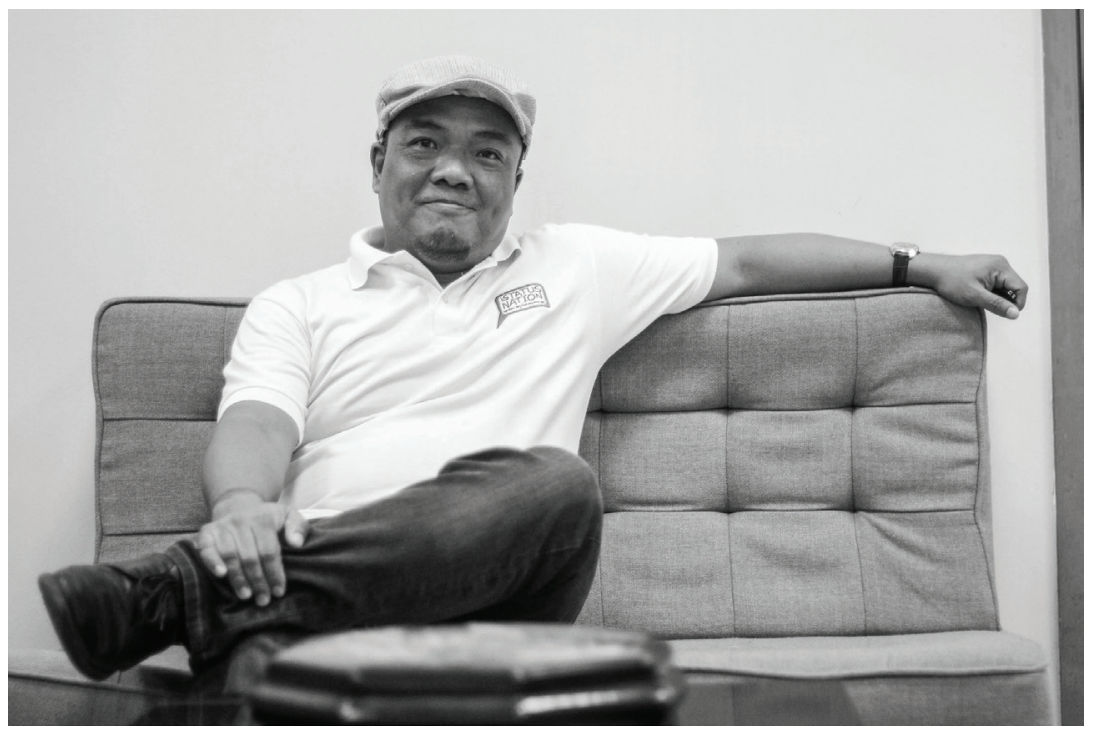

Fig. 2. Joselito Delos Reyes; https://varsitarian.net

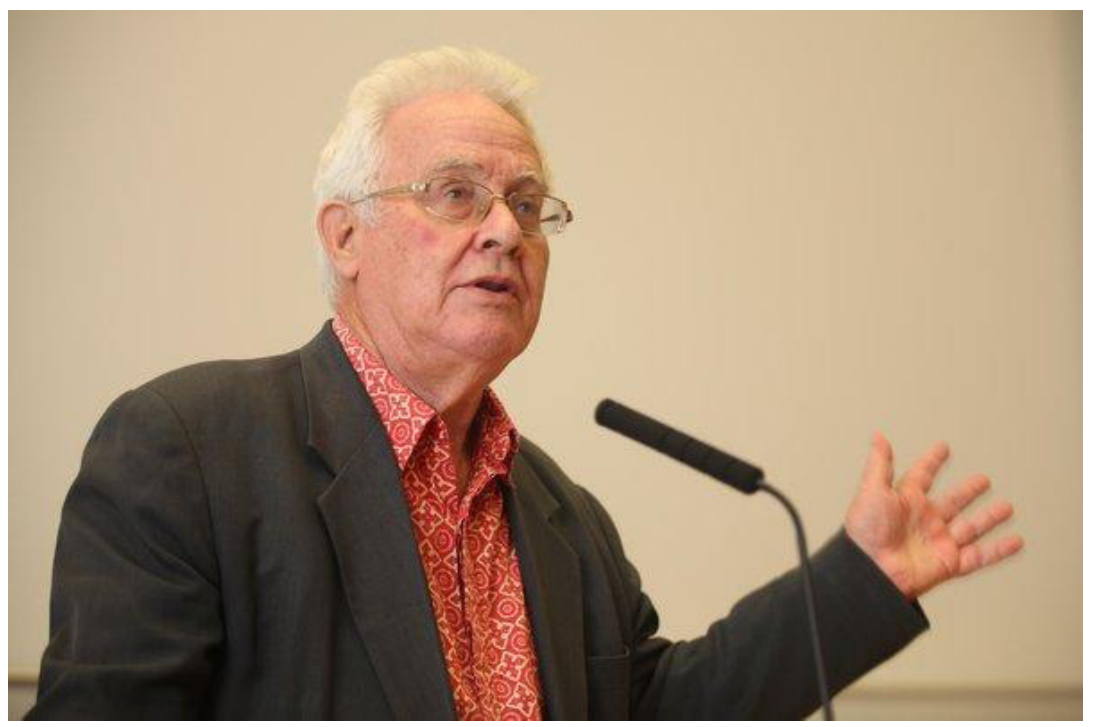

Fig. 3. Benedict Anderson, best known for his 1983 book Imagined Communities, which explored the origins of nationalism; https://www.nytimes.com 


\section{Introduction}

The 2016 national elections saw the emergence of Facebook as a battleground for many Filipinos expressing their support for their preferred candidates and their disdain for other candidates whom they believe would be detrimental to the country's progress. The heated disputes amidst a politically fractured Philippines did not just unfold via street protests and national debates on television but, in fact, also transpired online, particularly in the most popular social media platform: Facebook. In light of this, it is interesting to inquire and discern how Facebook, which has now become a ubiquitous means of communication and a predominant apparatus for discourse, has shaped the nation today-more specifically, how it has managed to fashion the identity of the modern Filipino concerning his relationship to the nation.

To examine this query, I felt compelled to look at Joselito Delos Reyes' iStatus Nation: Mga Istatus Kong Hindi Pang-status Quo, which won the 2015 National Book Awards for Best Book of Essays in Filipino. I believe that the distinctive form and nature of the book-a collection of the author's Facebook posts or statuses on various personal and social issues-make it a relevant and viable candidate for this examination. For this paper, I will look at iStatus Nation in conjunction with two pertinent texts: Benedict Anderson's Imagined Communities: Reflections on the Origin and Spread of Nationalism and Loreto Camiloza's paper, "Redefining Filipino Nationalism."

\section{Rethinking the Imagined Community}

Historian and theorist Benedict Anderson theorizes the nation as an imagined community thus:

It is imagined because the members of even the smallest nation will never know most of their fellow-members, meet them, or even hear of them, yet in the minds of each lives the image of their communion ... it is imagined as a community, because, regardless of the actual inequality and exploitation that may prevail in each, the nation is always conceived as a deep, horizontal comradeship (6-7). 
Anderson posits that the nation is a socially imagined community borne simply out of its members' imaginings largely due to non-interaction. In other words, the nation is, in essence, a mere image-or to use Jean Baudrillard's term, a simulacrum ${ }^{1}$ - of their communion or kinship. That the members of the community do not know and, thus, do not interact with each other is the basis of Anderson's theorization of the nation. I believe this is the interstice at which a rethinking of the nation as an imagined community lies. We presently live in the age of information and digital globalization where we are now able to communicate and engage with other people from everywhere in the world via social media. In this respect, the question begs to be asked: in the age of Facebook where members inside and outside a community can now interact with one another, is the nation, then, still imagined?

In their introduction to Critique, Social Media and the Information Society (2014), editors Fuchs and Sandoval postulate that "media, knowledge work and information technologies play a certain role in many contemporary societies and that the notion of the information society should therefore not simply be rejected, but critically assessed” (1). Facebook falls under the categories of "media, knowledge work and information technologies"; we can, therefore, deduce that it is a contributing factor to how the nation is now imagined or shaped. In our so-called “information society," I argue that the nation is no longer just imagined since it is now also physicalized in virtual spaces such as the various social media applications we presently have and partake in. In other words, Facebook has now become a tactile representation-a virtual microcosm-of the nation.

With this essential reshaping of the concept of the nation in the age of Facebook, how then do we reshape and re-imagine the Filipino? In Necessary Fictions: Philippine Literature and the Nation 1946-1980, Caroline Hau suggests that it is in literature where we go about preserving and reshaping Filipino culture:

Literature came to occupy a mediating position between the "universal" ideals of freedom and nationalism, on the one hand, and their realization within a specifically Philippine context, on the other hand. Literature assumed a mediating function precisely because Rizal's novels served as 
artifactual concrete examples of a "Filipino culture" that was conceived as the sum total of all the products of a society's creative labor and aspirations. At the same time, these works were the means by which other (later) Filipinos could acquire, preserve, and reshape such a culture (2-3).

Thus, I turn to the literature of Joselito Delos Reyes' to acquire some insight as to how the Filipino is reshaped by the "information society." As earlier mentioned, his iStatus Nation is an ideal case study for this inquiry as the book is a collection of essays collated from the author's very own Facebook page-as far as I know, the first of its kind in the country.

In the book, Delos Reyes writes with both humor and insight about the allures of his everyday life, choosing as subjects the following: his family, his profession as an educator, Philippine politics, and popular culture. In these Facebook-posts-cum-personal-essays, he not only entertains, informs, and provokes, but also manages to re-imagine the Filipino of today vis-à-vis his/ her attitude toward nationalism.

\section{Re-Rooting Filipino Nationalism}

In his paper "Redefining Filipino Nationalism," Loreto Camiloza argues that Filipino nationalism is confusing to Filipinos because the experience of decades of colonization has distorted their consciousness in that their principles, ideas, and lifestyles have been based on a Western perspective (35). Thus, he attempts to

redefine the meaning of Filipino nationalism by considering some aspects that are significant to its realization in the consciousness of the Filipinos such as Filipino nationalism in the context of imagined community, Filipino nationalism in relation to the development of print-language, Filipino nationalism in the context of blood relation, and Filipino nationalism in the context of virtue (3, emphasis added).

These contexts will serve as the framework of my examination of Delos Reyes' attitude towards nationalism in iStatus Nation. However, since I have already discussed Anderson's theory of the imagined community earlier, my discussion henceforth will focus on three questions that are based on 
Camiloza's redefinition of Filipino nationalism in the contexts of print-language, blood relation, and virtue:

1. How does print language, now embodied in the technology of social media, advance Filipino nationalism?

2. Do Filipinos still view nationalism in relation to blood or kinship to Inang Bayan (the Motherland)?

3. Is nationalism still considered a virtue amongst Filipinos?

This paper endeavors to answer these questions by analyzing the content of the book and extrapolating some insights on how Delos Reyes negotiates these questions.

\section{(Re-)Presenting the Filipino Netizen}

That iStatus Nation is neither fiction nor poetry but a work of creative nonfiction is pertinent. Much like those of millions of Filipino Facebook users, Delos Reyes' Facebook statuses are written observations on the events of his everyday existence. What sets his Facebook posts apart from that of the average user is that his are thoughtfully written and often humor-laden. Nonetheless, because his book is grounded in the real, it is poised to represent the daily plight of the common Facebooking Filipino.

The book is sectioned into four parts: Pop, Pol, Ser, and Emo. Each part concerns subjects or issues that are communal fixations of the modern-day Filipino: popular culture (Pop), politics (Pol), work or employment $(\mathrm{Ser})^{2}$ and relationships (Emo). ${ }^{3}$ On Facebook, it is common to see Filipinos sharing humorous memes about popular culture that would potentially become viral, ranting about the failures of the government, complaining about or extolling their line of work, and expressing their feelings, either positive or negative, about a loved one. Because his statuses are able to capture the interests of Filipinos on Facebook, Delos Reyes thus becomes a representation of that social-media-savvy citizenry. 
Clearly, iStatus Nation invokes issues that concern the nation. Particularly noteworthy is the title itself as it carries a play on words that operates on three levels: it is a direct description of the Philippine nation in relation to the popularity of social media; it is a critique on the Filipino's materialistic inclinations and obsession with social hierarchy; and, lastly, it is a self-reflexive statement on the status of the Philippine nation. It is, in essence, a pronouncement of three things:

1. the Philippine nation is composed of citizens who are fixated with posting their status on Facebook;

2. Filipinos seem preoccupied with social status; and

3. the book itself embodies the status of the nation-a wordplay on the State of the Nation Address (a. k. a. SONA). ${ }^{4}$

Judging by the book's pregnant two-word title, Delos Reyes makes a statement about the Philippine nation-immediately and urgently so. However, the subtitle-Mga Istatus Kong Hindi Pang-Status Quo-quickly counters, with irony and humor, the title's multi-layered statement. Humor and irony notwithstanding, the book just with its title, promises among others, references to, if not all-out discussions on, the nation. In fact, almost every page of the book exudes nationalistic sentiments-from ruminations about the plight of the Filipino teacher to a letter addressed to Janet Napoles to complaints about the ludicrously high 32\% tax that Filipinos were forced to bear during the leadership of Former President Benigno Aquino III. Like many of his fellowmen, Delos Reyes takes to the convenient platform of Facebook to express his concerns about the ills of society and engage other Facebook users who share, or disagree with, his sentiments.

Considering the notion of the nation as an imagined community, Delos Reyes, in iStatus Nation, re-imagines and (re-)presents the Filipino as a socially-engaged netizen in a Philippine nation no longer just imagined, but, in fact, physicalized in the virtual space that is Facebook. He not only re-imagines Anderson's member of a community as a netizen with a virtual identity engaging with other netizens in a simulated space, but also (re-)pres- 
ents them. I include the parenthetical (re-) in "(re-)present" to emphasize that Delos Reyes does two things here:

1. he re-presents-that is, presents in a new light-his re-imagined Filipino as a netizen (appropriating Anderson's citizen); and

2. at the same time, he represents-that is, assumes the role of a representative of-this re-imagined Filipino.

In his (re-)presentation of the Filipino netizen, Delos Reyes negotiates Camiloza's conceptions of Filipino nationalism in relation to three contextsprint language, blood relation or kinship to Inang Bayan, and virtue-by way of characterizing the modern Filipino thus:

1. acquiescent to the advancement of technology as an apparatus for social engagement and change;

2. inquisitive about the curiously and seemingly faulty machinations of the Inang Bayan as manifested in the nation's customs, traditions, and political governance; and

3. still fundamentally adherent to the notion of nationalism as a Filipino virtue that needs to be upheld.

\section{The Filipino in the Age of Facebook}

Anderson cites the newspaper and the novel-both products of print-capitalism-as contributory to the emergence of the nation. Of print capitalism, he writes, "Nothing perhaps more precipitated this search, nor made it more fruitful, than print-capitalism, which made it possible for rapidly growing numbers of people to think about themselves, and to relate themselves to others, in profoundly new ways" (36). What are perhaps the primary products of both print-capitalism and "information society" now are the gadgets that most of us use which can operate numerous social media applicationslaptops, smartphones, tablets, and so on. With the popularity of social media apps like Facebook, Instagram, and Twitter, it is clear that the masses 
embrace, with much fondness, this new technology (relative to the newspaper and the novel).

The Filipino netizen, as (re-)presented by Delos Reyes, is no different. In his Facebook entry "Migration," Delos Reyes writes:

Tungkol ito sa ating lahat na sumasandal na sa teknolohiyang kinakatawan ng mga gadget. Tungkol ito sa pag-iwan sa komportableng buhay mo sa isang lumang gadget patungo sa mas bago, makabago, at masakit sa ulong i-operate na gadget. Migration ang tawag sa pag-iwan at pagtungo sa panibagong teknolohiyang mangangailangan ng panibagong kaalaman $(73) .^{5}$

Here, Delos Reyes (re-)defines the word "migration" in technological terms, which includes both physical and sociological transference from one gadget to another-from the old to the new. The acknowledgment of this so-called "technological migration" establishes the value that the Filipino netizen places on new technologies. While Delos Reyes expresses his frustration over the occurrence of this new type of migration by describing the process as complicated and headache-inducing, he ultimately recognizes the need to acquiesce to this migratory advancement by suggesting that the Filipino netizen, in order to progress, must not be impervious to new knowledge.

In "Facebooking," Delos Reyes traces the journey of his migration from Friendster ${ }^{6}$ to Facebook. A friend set up a Facebook account for him in May 2009, but he admits to not touching the strange application with the new interface until months later. It was only in December 2009 that he actually started using Facebook-studied its workings, uploaded a profile photo, liked other Facebook users' posts and photos, and posted his own statuses. Eventually, he learned to appreciate and enjoy Facebook as other users began liking his witty and humorous statuses, family photos, poems, and shared links-whether the posts were sensible or silly did not matter to the likers. He even confesses that Facebook was particularly helpful to him in completing his graduate thesis (16-17).

Delos Reyes' personal account of his migration to Facebook speaks of the Filipino netizen's eventual discovery of Facebook as a refreshingly social, albeit synthetic, space. The once-solitary nature of computer technology is 
no longer so; through social media, it is now socially vibrant, stimulating, engaging, and interactive. The Filipino netizen cannot help but yield to the allures of Facebook; he embraces this new technology as it appears to curb loneliness and isolation, and offers a welcome escape towards social engagement and productivity.

\section{Sending Tough Love for the Motherland}

What is perhaps most fascinating about Filipino nationalism is its perceived subjectivity. Camiloza, in his study on the nature of Filipino nationalism, provides some insight thus:

Filipinos establish and found [sic] community as the basis or foundation. Filipino nationalism is not only known; it is also deeply felt and acted out in the spirit of blood relation ... . Symbols, myths, values, memories, attachments, customs, religion, laws, institutions, routines, and habits are intrinsic aspects that make up our blood relation and the complexity of the Filipino nation (41).

Camiloza adds that Filipinos are inclined to regard the nation as Inang Bayan (the "Motherland"); Filipino nationalism is therefore deeply entrenched in the relation between "the nation as a mother and Filipinos as sons and daughters" (41). The personal nature of this mother-and-son relationship between the nation and the Filipinos manifests in the way the latter affects, with much fervor, the former's governing mechanisms-e.g., the government, laws, customs, traditions, values, and so on. Because nationalism, to the Filipinos, is about identity and survival, they are passionate in their stand against faulty elements of the Motherland that pose a threat to the integrity of the nation. A resounding case in point would be the People Power revolution that toppled the oppressive regime of President Ferdinand Marcos.

In the age of social media, we still see the same passion and urgency to right the wrongs of society, albeit taking on the forms of comments, rants, and memes in the walls of Facebook. Regardless of the form, however, the impassioned nature of Filipino nationalism is still alive today; and Delos Reyes, as representative of the Facebook netizen, exudes this nationalistic 
spirit by questioning the operating mechanisms of Inang Bayan. In the book, he comments on, contests, and critiques the Motherland's government, as well as her customs and traditions.

As of this writing, "Dear Janet" -Delos Reyes' most famous and most shared Facebook post-has garnered 334 comments, 25,000 likes and 35,094 shares. It is an open letter written in August 2013 to Janet Napoles, a businesswoman who had scammed, in conspiracy with numerous politicians, mostly senators and congressmen, the Filipino people of their taxes in the billions. Delos Reyes writes:

... susulat na lang muna ako. Ito ang kaya kong gawin. Kaya hindi muna ako makakalimot. Iuukil ko sa sinumang makakabasa at makakarinig sa akin na pwede ba, huwag muna tayong makalimot. May oras at araw kayo. Huwag munang makalimot hanggang dumating ang araw ninyo. Darating ang araw ninyo kapag sinabi at sineryoso na nung nakatira sa Malakanyang, ${ }^{7}$ yung tao na laging nag-i-invoke na ako ang boss niya at dapat maglakad ako sa kaniyang tuwid-na-daan, ${ }^{8}$ na parusahan kayong makulong sa tunay na kulungan at hindi sa resort na kung tawagin ay St. Luke's o Veterans ${ }^{9}(163){ }^{10}$

It is no surprise that the above Facebook post went viral as it has touched a chord in the Filipino people with its combination of humor, wit, and zeal. It embodies a voice that shares the sentiments of many irate and flabbergasted citizenry who felt swindled both by Napoles and the government. More than just a letter to Napoles, it is a critique of the government's ineffective leadership, a statement against corruption, and a resounding reminder to the Filipino people not to fall victim to social amnesia. After all, a crime of such magnitude should never be forgotten.

What the letter-cum-Facebook-status also highlights is the power of both writing and social media. Delos Reyes manages to use this Facebook post as a potent tool-a kind of manifesto-to decry corruption, and thus incite social engagement and, hopefully, change. That the post has attained internet virality through likes, comments, and shares is a testament to the existence of Facebook nationalism. Delos Reyes, by calling out the faults of the nation's government, and the other Facebook netizens, by participating in the discourse, show no reluctance in challenging the Motherland. 
Questioning her, particularly the inefficacy of her fractured system, is, after all, intentioned with love and concern.

If in "Dear Janet" Delos Reyes criticizes the government, in "Manahimik $\mathrm{Na}$ Lang" ("Just Shut Up"), he calls out fellow Filipino netizens whose line of reasoning he deems flawed. I will quote the post in full:

Nagsimula ang line of reasoning na ito noong isang linggo. Iyong "manahimik na lang" tapos sasamahan ng variant na "tumulong ka na lang kesa mag-rant" at "Ikaw, ano ang naitulong mo?"

Hindi ko gustong isipin na spin ito ng mga nakatira sa malaking gusali malapit sa Mendiola (hindi Beda, hindi CEU, starts with the letter $\mathrm{M}^{11}$ [sic]. Sablay naman kasi talaga. Kaya to prevent the popularity nose-dive, kelangan ng counter propa. Yes, propa.

Pansinin, sa dami ng nagra-rant, ganoon din ang nagsasabi ng manahimik na lang. May kakaiba ba rito? Oo, yung nagsasabing manahimik at tumulong, sila yung nakatutok sa mga nagra-rant, consistent. Rant sa rant. Ano? Bantay sa mga kritiko? Para ma-sanitize? Yung nagsasabing manahimik, hindi rin tatahimik.

Protektado ng Konstitusyon ang karapatan kong mag-rant sa $\mathrm{fb}$. At ang pagtulong? Hindi ako naniniwalang dapat ipinagsasabing nakatulong ako. Mag-rant tayong pareho o manahimik tayong pareho (134-135). ${ }^{12}$

“Manahimik ka na lang!" pervades the comment sections of controversial posts of Filipino netizens who are fearless in giving a piece of their mind on contentious issues hounding the nation. In his entry, Delos Reyes condemns this kind of argumentation that is clearly devoid of logic. He critiques the Filipino's propensity for crab mentality, where one derisively regards views opposed to him as inferior and attempts to demean the opponent through lies or other malicious means. He also upholds the basic human right of freedom of expression; and ranting on Facebook, he reminds us, is covered by that Constitutional right.

In today's information society, the Facebook netizen, as represented by Delos Reyes, expresses his commitment to and concern for the nation-the Motherland-not only by highlighting its strengths but also by bringing 
attention to its weaknesses-be it the ineffective governance of its political leaders or the flawed traditions and practices of its citizens.

\section{Is Nationalism Still a Filipino Virtue?}

It is said that love for one's nation translates to love for one's neighbors; thus, it can be said that nationalism is akin to altruism. In his study, Camiloza posits that "Filipino nationalism is a virtue that cannot be divorced from the Motherland's goal, which is the source of her survival as a nation" (42). He further writes:

Filipino nationalism is a commitment and willingness to live, to think, to judge and to sacrifice one's self for the common good of the Motherland. As a virtue, it is perfected through constant commitment of the will not for one's own sake but for the good of all Filipinos. It is a virtue for it directs every Filipino to act towards the good, the common good (42).

The Filipino brand of nationalism as a virtue is highlighted by selflessness and sacrifice for the common good. In iStatus Nation, Delos Reyes exemplifies this practice of selflessness particularly in his profession as an educator. In “Bakit Ako Naging Titser?" ("Why I Became a Teacher?"), he posts:

Sa pagharap ko sa mga mag-aaral, pakiramdam ko, may hindi kayang ibigay ang bayang ito na tanging guro lamang ang makapagpo-provide. Basta ganun. Pakiramdam ko bayani ang maging guro (na totoo naman sa dami ng gawain at liit ng suweldo). Pero hindi agad ako naging guro. Not in the strictest sense though.

Pakiramdam ko, if you could make a dent out of not [sic] this wretched world, somehow, you make this world a better place to live in. Contribute ka lang. Kaisipang "solusyon ako at hindi problema." So hanggang ngayon, bitbit ko pa rin ang prinsipyong iyan. Saang paraan ka magko-contribute to make this world a better place to live? Ang maging titser ang pinakamagaling. Kaya ako masaya (222). ${ }^{13}$

In this Facebook entry, Delos Reyes espouses teaching as a noble but thankless (monetarily, at least) profession. He describes this line of work as 
somehow able to provide something to fill a void that the country cannot fill. For him, teachers function with the right kind of mentality-becoming a solution rather than the problem. Despite enduring a heavy workload and meager pay, teachers nonetheless find joy and fulfillment in their profession. This is where self-sacrifice comes in: teachers work tirelessly and selflessly to educate the youth despite limited financial rewards. Teachers think of the nation first and foremost, and themselves only second. In this regard, it can be inferred that, for Delos Reyes, teaching is an act of nationalism embodying the virtue of selflessness and the practice of self-sacrifice.

In "Group Work," Delos Reyes shares his philosophy on assigning group activities to his students. He tells his students that all members of each group will get one and the same grade. Though some of his students would complain that it is an unfair practice since some of the group members don't pull their weight and only rely on others' efforts, he stands firm with his rules on group work. He rationalizes this by explaining to his students that, beyond the school grounds, in the real world, we don't get to choose whom we work with; rather, we make the best of our situation no matter how unfavorable it might be. We learn how to deal with difficult circumstances; and work involving group activities in school is good practice. In addition, he maintains this philosophy as it upholds the virtue of sacrifice as well as the principle of karma:

Nasa kakayahan ng iba na magtrabaho para sa walang ginagawa. Ang natamong higit na kakayahan habang binabalikat ang isang pabigat na kasapi ay sobra pa sa makukuhang marka. Put premium on experience (mas maganda ang termino sa Filipino, "danas") para gampanan ang gawaing hindi pangisahan. Paniniwala ko, ang pakikitungo sa inutil hanggang mahikayat mo siyang makipagtulungan ay malaking pakinabang na sa paghahanda bilang propesyonal, bilang maaasahang mamamayan ng bansang ito (189). ${ }^{14}$

Here, Delos Reyes emphasizes the value of sacrifice in the context of group work, particularly the willingness to perform extra work to compensate for a group member's lack of effort. He highlights the fact that doing temporary sacrifices can lead to even bigger rewards in the future such as the valuable 
experiences and additional aptitudes gained. In fact, these rewards would even prepare a person for the professional world and transform him or her into a responsible citizen. He adds that the law of karma works, too: temporary sacrifices promise future successes, and, later in the essay, laziness and irresponsibility eventually result in unsatisfactory comeuppance such as losing opportunities for being notorious as a slacker. This Facebook entry punctuates that self-sacrifice is deeply ingrained in Filipino nationalismthat choosing to work for the common good eventually pays off not only on a personal level, but also on a bigger, societal level.

\section{Instant Authors and Fake News:}

\section{Ramifications of the Re-Imagined Nation}

What is arguably the greatest achievement of social media is the democratization of publishing. Anybody with a Facebook or Twitter account can now self-publish-and with incredible ease and immediacy at that. One needs only a gadget with internet access to be able to put out a piece of writing, a photograph or a video onto the virtual space shared by a group of people. In Anderson's imagined community, print language costs serious money and takes a long time to produce. Information needs to be researched and synthesized into organized texts, which then need to be written, collated, and edited before they can be turned into books and subsequently released to the members of the community for consumption. That is the case for both novels and newspapers, although in the case of the latter, the process is much shorter and quicker since newspapers are published on a daily basis. But just the same, gathering and disseminating news take time, money, and manpower before they can reach the reading public.

In Delos Reyes' re-imagined nation, however, the process of publishing is faster, cheaper, and more dynamic since print language has been overtaken by social media. Any netizen has the capability to publish and share his or her thoughts, opinions, and sentiments on a particular issue instantly via social media apps like Facebook. There is no need to painstakingly craft a manuscript and submit it to a publisher for publication. There is no need to spend a great deal of either time or money just to express one's views to be shared 
to the rest of the community. And once a netizen posts his or her thoughts and opinions on social media, other netizens may instantly like, comment, and share, making way for a more interactive and dynamic virtual space. In other words, since social media has now afforded members of a community a convenient and practical platform that enables them to instantly interact and become instant authors, what he have now is a nation that is no longer imagined, but re-imagined or, in fact, real.

If there is one thing that significantly differentiates the re-imagined nation from the imagined community, it is the combined sense of ease, immediacy, and interaction in the distribution of information that privileges members of a community with instant authorship. That is the biggest appeal of social media: everyone is able to exercise their freedom of speech and expression-and with this, the possibility of internet virality and thus, instant fame. While this is a boon for the exercise of the freedoms of speech and expression of the individual, this also poses a big problem: the disintegration of moral and ethical responsibilities and standards in the handling and sharing of information.

What Anderson's imagined community carries is a paradox: on the one hand, the downside of the production of print language is its tediousness and limited accessibility; on the other hand, however, it is also an advantage in that information is regulated and controlled. The creation of print language involves a process of policing, whereby editors and publishers screen, edit, fact-check, and proofread all the information that go into the manuscripts and drafts before they get published into books and newspapers. In other words, what ends up in the hands of the members of the community for their consumption are accurate information that passed professional and ethical standards.

This, however, is not always the case in Delos Reyes' re-imagined nation. Because all netizens can become instant authors in social media, information, at times, gets shared and passed around irresponsibly and even maliciously. We see this happening in the country at the moment with the proliferation of fake news where information, quite disconcertingly, is wantonly weaponized to malign, offend, and destroy. Facebook now sees the explosion of trolls and 
attack dogs who are compensated to conduct historical revisionism in order to push a certain agenda. Ordinary netizens naturally react and take sides; many engage, not in calm and sensible discourse, but in hateful arguments peppered with false claims and ad hominem attacks.

Social media has certainly democratized publishing; unfortunately, it has also led to the normalization of hate speech, where netizens with a misguided or misplaced sense of nationalism fall prey to both misinformation and disinformation. Sadly, this malicious handling and manipulation of information has caused divisiveness in the country-the exact antithesis of what Anderson theorizes and upholds in Imagined Communities: the communal effort of a group of people to come together, despite non-interaction, to form a united nation.

\section{Conclusion: The Rise of the Facebook Nationalist}

In this paper, I have tried to argue that, in the age of Facebook, the nation is no longer just imagined since it is now also physicalized in a virtual spacethat Facebook has now become a synthetic microcosm of the nation. In addition, I have also posited that, in iStatus Nation, author Joselito Delos Reyes re-imagines and (re-)presents the modern Filipino as a socially-engaged netizen who embraces new technologies that further social engagement and change, who inquires and questions the faulty workings of the Motherland, and, lastly, who still considers nationalism as a Filipino virtue.

I began this paper with a discussion of Facebook as a kind of combat zone for many politically passionate Filipinos who express either their support or contempt for certain political leaders. I wish to conclude this paper in the same vein. For what this nation has witnessed of late is a phenomenon that is both fascinating and troubling: the apparent rise in number of what appears to be Facebook nationalists. Fascinating because we now see Facebook as a convenient avenue for certain groups to self-organize and self-mobilize. It is now easier to start petitions for social change via social media, and to take to the streets to protest and fight for what people think is right. It is all well and good if what is being fought for is, indeed, what is right. However, the rise of Facebook nationalists is also troubling because, as we are all well aware, 
nationalism, when placed in the wrong hands, has the potential to cause social fracture and fuel, once again, the death of a nation's freedom. 


\section{Notes}

1. See Jean Baudrillard's Simulacra and Simulation (1994).

2. A Tagalized version of the English word "Sir," a common address to male teachers.

3. Short for the word "emotional." In Philippine popular culture, "emo" refers to someone who is more emotional and gets easily attached to things than others.

4. An annual speech delivered by Philippine presidents to inform the public of the country's current economic state relative to goals previously set.

5. Translation:

This is about all of us who rely on technologies embodied by gadgets. This is about leaving the comforts of an old gadget towards a new, headache-inducing, more complicated gadget. Migration is what you call your desertion of an older technology in favor of a newer one that requires new knowledge (73).

6. A popular social networking site in the early 2000s.

7. Referring to Benigno "Noynoy" Aquino III, whose official residence, as former President, should have been Malacañang Palace but who chose to live in Bahay Pangarap (or House of Dreams) inside Malacañang Park.

8. President Noynoy Aquino often referred to the Filipino as his "boss." He called his political platform as "Daang Matuwid" or "Straight Path."

9. St. Luke's Medical Center and Veterans' Hospital, where several politicians found guilty of graft and corruption stayed after feigning sickness.

10. Translation:

... I will just write. This is what I can do. So I will not yet forget. I will force upon anyone who can read and hear me that we not forget. Your time and day will come. Do not forget until that day comes. That day will come when that person who resides in Malacañang, that person who always invokes that I am his boss and that I should follow the straight path, finally takes his job seriously and proclaims that you should be punished and sent to a real jail, not to a resort named St. Luke's or Veterans (163).

11. "Beda" refers to San Beda College, CEU is Centro Escolar University, and the building that starts with the letter "M" is Malacañang Palace. All establishments are situated in the same vicinity.

12. Translation:

a. This line of reasoning started last week. The "Just shut up!" then followed by a variant of "Why don't you just help out rather than rant?" and "How about you, what kind of help have you given?" 
b. I don't want to think that this is a spin by those people who live in the big building near Mendiola (not Beda, not CEU, starts with the letter M). It's just so messed up. To prevent the popularity nose-dive, there needs to be counter propaganda. Yes, propaganda.

c. Get this, the number of people of those who rant is the same as the number of those who say "Just shut up!" Is there something odd here? Yes, those who say "just shup and help" are the very same people who are after those who rant-consistent. Rant for rant. What, they are guarding the critics? To sanitize them? Those who say "shut up" will never shut up.

d. My right to rant on FB is protected by the Constitution. And the act of helping? I don't believe that one should brag about the fact he has helped others. We should both rant or we should both shut up. (134-135)

13. Translation:

a. When I face the students, I feel that there is something that this country cannot provide that only teachers can. Really, it's like that. I feel that teachers are heroes (which is true with their heavy workload and small salary). But I didn't become a teacher right away. Not in the strictest sense.

b. Ifeel that if you could make a dent out of this wretched world, somehow, you make this world a better place to live in. Just contribute. The mentality that "I am the solution and not the problem." So until now, I still carry that principle with me. In what way will you contribute to make this world a better place to live in? To be a teacher is the best. That's why I'm happy (222).

14. Translation:

a. Some are capable of also doing the work of those who do nothing. The extra abilities gained while shouldering the work of a lazy freeloading group member are much bigger rewards than the grade received. Put premium on experience (the Filipino term is better, "danas") in performing group work. I believe that the ability to work with an inutile member until you are able to encourage him to share the work is a big advantage in preparation for becoming a professional, a dependable citizen of this country (189). 


\section{Works Cited}

Anderson, Benedict. Imagined Communities: Reflections on the Origin and Spread of Nationalism. Revised ed., Anvil Publishing, 2016.

Camiloza, Loreto G. "Redefining Filipino Nationalism." Journal of the Humanities, vol. 2, no. 1, 2007, pp. 35-43.

Delos Reyes, Joselito. iStatus Nation: mga Istatus kong Hindi Pang-Status Quo. Visprint, Inc., 2014.

Fuchs, Christian, and Marisol Sandoval, editors. Critique, Social Media and the Information Society. Routledge, 2014.

Hau, Caroline S. Necessary Fictions: Philippine Literature and the Nation 1946-1980. Ateneo de Manila UP, 2000. 